\title{
Patriarchal Regime of the Spectacle: Racial and Gendered Gaze in Jhumpa Lahiri's Fiction
}

\author{
Moussa Pourya Asl (Corresponding author) \\ School of Humanities, Universiti Sains Malaysia, PO box 11800 USM, Pulau Pinang, Malaysia \\ E-mail:ms_pourya@yahoo.com \\ Nurul Farhana Low bt Abdullah \\ School of Humanities, Universiti Sains Malaysia, PO box 11800 USM, Pulau Pinang, Malaysia
}

Received: 17-10-2016

Published: 01-03-2017
Accepted: 08-12-2016

doi:10.7575/aiac.ijalel.v.6n.2p.221
Advance Access Published: January 2017

URL: http://dx.doi.org/10.7575/aiac.ijalel.v.6n.2p.221

\begin{abstract}
This article attempts to evince the political, cultural and affective consequences of Jhumpa Lahiri's diasporic writings and their particular enunciations of the literary gaze. To do so, it details the manner in which the stories' exercise of visual operations rigidly corresponds with those of the Panopticon. The essay argues that Lahiri's narrative produces a kind of panoptic machine that underpins the 'modes of social regulation and control' that Foucault has explained as disciplinary technologies. By situating Lahiri's stories, "A Real Durwan" and "Only Goodness," within a historicalpolitical context, this essay aims at identifying the way in which panopticism defines her fiction as both a record of and a participant in the social, sexual and political 'paranoia' behind the propaganda of America's self-image as the land of freedom. We maintain that Lahiri's fiction situates itself in complex relation to the postcolonial concerns of the late twentieth century, suggesting that through their fascination with a visual literalization of the panoptic machine, and by privileging the masculine gaze, the stories legitimate the perpetuation of socially prescribed notion of sexual difference.
\end{abstract}

Keywords: Gaze, Sexual difference, Panopticon, A Real Durwan, Only Goodness

\section{Introduction}

In its visual acuity, Jhumpa Lahiri's fiction seems to be so appealing that she has quite recently enjoyed an extraordinary success by winning America's 2014 National Medal of Arts and Humanities. At the awards ceremony, the US President applauds Lahiri for her realistic and "truthful" representations of Indian American experience and opens his address as,

One of our great poets, Emily Dickinson, once said that 'truth is such a rare thing, it is delightful to tell it.' The truth is so rare, it is delightful to tell it-- and that's especially true in Washington. (Laughter.) ... The men and women that we honor today, recipients of the National Medals for the Arts and the Humanities, are here not only because they've shared rare truths, often about their own experience, but because they've told rare truths about the common experiences that we have as Americans and as human beings. .... The 2014 National Humanities Medal to Jhumpa Lahiri for enlarging the human story. In her works of fiction, Dr. Lahiri has illuminated the Indian American experience in beautifully wrought narratives of estrangement and belonging. [italics our emphasis]. (Obama, 2015)

But in what ways can we speak of Lahiri's fiction as a truthful image? How closely, for instance, does she portray a single moment or a specific event in Indian diasporic lives? Is it meant to tell the whole truth? Or is it meant to tell a carefully selected and unexpected, hence 'rare and delightful', truth? In Television, Jacques Lacan argues telling the whole truth is impossible: "I always speak the truth. Not the whole truth, because there's no way to say it all. Saying the whole truth is materially impossible; words fail. Yet it's through this very impossibility that the truth holds unto the real" (as cited in Copjec, 1989, p. 287). But, what is at stake when truth is not actually said, whether the whole, or in part? Who benefits? The guest, the Indian immigrant, or the host, the capitalist US? In terms of these questions, it was Gayatri Spivak's "old-fashioned Marxist" agenda that first focused attention on the possibility of the immigrants' being exploited by the "orthodox constraints" of the "neo-liberal" America. In her demonstration of the extent of this exploitation, Spivak (1999) observes, "Marx attempted to make the factory workers rethink themselves as agents of production, not as victims of capitalism .... By analogy with the Marxist project ... the hyphenated Americans ... might rethink themselves as possible [Spivak's italics] agents of exploitation, not its victims" (p. 357). This possibility is to a high degree reflected in the US President's earlier remarks that he always does "pretty good with writers" and regards them as his "crew". The significance of these words is even further highlighted when one notes the political nature of Lahiri's writings. In a recent collaborative scholarship to name and categorize her, Dhingra and Cheung (2012) conclude that "Lahiri's characters ... live in a more de-racialized and de-classed U.S. political landscape than is the 
socio-historical reality, especially in a post 9/11 world hypersensitive to 'brown folks,' irrespective of class, nationality, and religion" (p. xvii). Perhaps this is the reason Lahiri is acknowledged by the host country for her telling "rare truth about the common experience". But the question still remains unanswered: In what ways can we speak of this experience as truthful? Is it telling the whole truth? Is this possible?

Judith Fetterley (1997), in a kind of establishing shot, summarizes what we also take to be the central issue here, a misconception in which there is: "the pretense that literature speaks universal truths" [my emphasis] (p. 564). Fetterley charges American literature with a "limited vision", arguing that it encourages, legitimizes, and transmits only "one reality." American fiction is "frequently dedicated to define what is peculiarly American about experience and identity" [our emphasis] (p. 564). In this context, whether Lahiri's fiction as a whole is viewed as utterly truthful, or narrowly (mis)representing the Indian diaspora seems to be an interminable controversy among scholars: While some applaud her sociologically realistic portrayals of Indian Americans (Dhingra and Cheung, 2012; Koshy, 2013), others accuse Lahiri of misrepresentation and exoticism (Lynn, 2004; Srikanth, 2012; Mani, 2012; Asl, Hull, \& Abdullah, 2016; Asl, Abdullah, \& Yaapar, 2016). These contrasting views inevitably lead to a constant naming, misnaming, and re-naming of Jhumpa Lahiri in terms of the complex relationship between her ethnicity and Americanness.

Fetterley's position that "literature is political" is also advocated by many other scholars. In a critique of imperialism, for instance, Spivak (1997) warns that "the role of literature in the production of cultural representation should not be ignored" (p. 896). In a similar way, for Foucault, literature operates as an apparatus utilized by the disciplinary state to disseminate socially prescribed standards. But what makes Fetterley's position particularly important for our concerns, is her statement that "American literature is male" (1997, p. 564). The universality that American literature insists on is, at the same time, defined in specifically masculine terms. "Given the pervasive bias of this literature," Fetterley asserts, "it is not surprising that in it the experience of being American is equated with the experience of being male" (p. 565). In this context, we do not have far to travel from Fetterley's notion of biased American literature, to Laura Mulvey's pursuit of social "contradictions" and "mechanisms" of visual pleasure inherent within the patriarchal culture of the US.

In "Visual Pleasure and Narrative Cinema," Mulvey (1975) points to the existing sexist-norms at work within the phallocentric structure of Western thought. She argues that within the traditional social structure, the woman stands as signifier for the male other, "tied to her place as bearer of meaning" (p. 7), rather than maker of it. She is passive, the object, the one who "holds the look, plays to and signifies male desire" (p. 11). In contrast, the man is privileged with an active role, as the subject, one who gazes, the one who sees. In this manner, Mulvey draws attention to the look's "active/passive heterosexual division of labour" operating within this dominating phallocentric order of the state. But what is beyond this physical dimension of vision? What is at stake when the mainstream culture is pre-occupied with the visual? Regarding this question, one has to note that although the literary gaze, as caused by its simultaneously exploitative and capitalistic apparatus, constructs for the reader a voyeuristic modality loaded with the exciting pleasures of mastery and control (Mulvey, 1975; Metz, 1997), "this is not voyeurism's sole affectivity" (Hurley, 1997, p. 5). Scopophilia, Shaviro suggests, is "the opposite of mastery: it is rather a forced, ecstatic abjection before the image.... Voyeuristic behavior is not willed or controlled by its subject: it is a form of captivation, in which passivity is pushed to the point of automatism" (as cited in Hurley, 1997, p. 48). Mulvey (1975) thus develops her argument-i.e. the "image of woman as (passive) raw material for the (active) gaze of man"-a step further into the structure of representation, arguing that "the structure of looking in narrative fiction ... becomes the mechanism for producing an illusion ... compatible with the human eye, an ideology of representation that revolves around the perception of the subject" (p. 18). From this sexual politics of looking, a pivotal question is raised by Newman (1990): "Is it possible to elude the patriarchal regime of the spectacle in representations of gender?" (p. 1032). Mulvey concludes that "reality, obviousness and truth" cannot be achieved in fictional drama (1975, p. 18).

In this theoretical rendering, literature as an apparatus thus acts to instantiate in its readers the ideological interests of the capital that mobilizes the apparatus itself, doing so through narrative techniques that conscript readers into a literary illusion, so that their gaze on the text, the gaze of the characters within the text, and the gaze of the narrator (as the surrogate of the author) are organized into a unified scopic regime. The literary gaze then comprises this very scopic regime, the reader's gaze absorbed into the illusion presented within the fiction-discourse, and then re-structured as the fiction-discourse, in such a way that the reader reads and sees as the story does, with a gaze that provides the delightful illusion of transcendence, but which in fact is in accordance with the institution of the literary work and its ideological investments. How might, then, a truthful representation of gender roles possibly find expression in the Indian American diasporic literary productions of Jhumpa Lahiri? What modes of visual relations are established? Why and to what political effect? Does she elude the patriarchal regime of the specular? This essay pursues these questions through an examination of existing gender relations in Lahiri's short stories "A Real Durwan" and "Only Goodness", from her short-story collections Interpreter of Maladies (1999) and "Unaccustomed Earth" (2008), respectively.

In situating Lahiri's stories within a panoptic system, the present essay in a way repeats Lahiri's own scrutiny - by enunciating itself as a critical gaze. If Lahiri's diasporic gaze works to objectify and relocate subjects, often into positions they might never otherwise go ${ }^{\mathrm{i}}$, the study's critical gaze insistently re-positions these writings, locating them in new contexts, opening up their fiction-discourse into discourses the stories themselves might want not to set foot in. In this manner, this essay endeavors to evince the political, cultural and affective consequences of Lahiri's diasporic writings and their particular enunciations of the literary gaze. To achieve this goal, we aim to detail the manner in which the stories' exercise of visual operations rigidly corresponds with those of the Panopticon. We argue that her narrative produces a kind of panoptic machine that underpins the 'modes of social regulation and control' that Foucault has 
explained as "disciplinary technologies", the set of material elements and "techniques that serve as weapons, relays, communication routes and support for the power and knowledge relations that invest human bodies and subjugate them by turning them into objects of knowledge" (1995, p. 28). In addition, this essay situates Lahiri's stories within a historical-political context, identifying the way in which panopticism defines Lahiri's writings as both a record of and a participant in the social, sexual and political 'paranoia' behind the propaganda of America's self-image as the land of freedom. We maintain that Lahiri's fiction situates itself in complex relation to the postcolonial concerns of the late twentieth century, suggesting that through their fascination with a visual literalization of the panoptic machine, and by privileging the masculine gaze, the stories legitimate the perpetuation of socially prescribed notion of sexual difference.

By locating Lahiri's short stories "A Real Durwan" and "Only Goodness" within this critical context and examining her literary engagement with the phenomenon of truthful representations of gender, this essay expands upon recent scholarship in transnational feminism that has turned to the concept of anticapitalism as a way of opposing the homogenization of the experiences of postcolonial women, a critical oversight within studies of contemporary western feminism (Mohanty, 2014). This scholarship has criticized the way that postcolonial narratives, in their supposedly accurate representations, most often valorize American values rather than decentralize the dominant power hierarchies (Ganguly, 2001; Grewal, 2005). In these accounts, the Indian American women writers' attempt to assert their individuality turns into a "somewhat dubious" situation (Spivak, 1997, p. 40) because, paradoxically, they operate "at best [as] native informants for first world intellectuals interested in the voice of the Other" (Spivak, 1988, p. 284). With this in mind, even the commendation of Lahiri for her "precise, evocative and convincing" depiction of Indian immigrants by some (Western and American) critics, ironically works against her by inciting other critics to express doubt and suspicion over her credibility as a voice for the Asian or Indian diaspora. A few scholars (Dhingra, 2012; Reddy, 2013), however, exclude Lahiri from the circle of contemporary diasporic South-Asian American woman writers - such as Bharati Mukherjee, Chitra Divakaruni, and Meena Alexander - arguing that her writings transcend and challenge the Asian American "gender troubles" paradigm of earlier Bengali American writers, and provide alternatives to Asian American conventional gender roles ${ }^{\text {ii }}$.

Paradoxically, Dhingra (2012) pays tribute to Lahiri for providing new definitions of masculinity, claiming that her male characters form the mainstay of Lahiri's writings, and that even in those stories in which the protagonist is female, her "male characters play a critical role to influence the action and the point of view" (p. 140). Dhingra takes this as an act of Lahiri's nationalistic loyalty ${ }^{\text {iii }}$ towards her male protagonists and praises her for finding a way to "renegotiate the (Asian) American sexual politics" by even-handedly looking at men and women together. We concur with Dhingra that Lahiri gives her male characters hetero-normative roles, and by doing so portrays them as essentially nurturing, giving and forgiving, but what is not sufficiently discussed is why, in the process of "looking at men and women together", Lahiri becomes less sympathetic and more satirical toward women, insofar as far from writing in favor of "the ethos of millennial female license," affirms Cussen (2012), Lahiri “writes against that ethos" (p. 7), and parodies the woman's nature. The following two sections focus on Lahiri's preoccupation with the act of looking and examines the constituted gendered and racial hierarchies.

\section{A Benthamite Panopticon}

"A Real Durwan"iv is a story about an increasingly frail sixty-four-year-old woman, called Boori Ma ("Old Mother"), who has taken up residence in the basement of an apartment building of Calcutta. Boori Ma works as the durwan (gatekeeper) to the building, and each day, she has to clean the stairwell and establish orderliness, for which, in return, she gets to sleep behind the gate and perhaps an occasional free cup of tea. As she sweeps the stairs, she details the losses - her separation from her husband, two daughters, and the easier, luxurious times in her life-she has suffered because of the Partitionv, Boori Ma spin stories about her past, the feasts, servants and marble floor of her home, many of which, the residents believe she has exaggerated or made up, thus wrapping herself in nostalgic illusion. Boori Ma turns out to be a pretty good durwan, keeping the place spotlessly clean and turning away any suspicious-looking person. As befitting the role of monitor, she wanders in and out of the apartments, her major duty being simply to keep the outside world at bay. But, what diminishes Boori Ma's vigilance, as we are told by a highly informative third-person omniscient narrator, is that she suffers from sleepless nights, and while on duty, is prone to wander around the town, leaving the building by itself. One day, when she gets back home, she notices the newly installed basin of the Dalals' has been torn out of the wall. Almost all the residents suspect her and accuse her of conspiring with the robber, and unanimously agree on tossing Boori Ma out of the building and seeking for a new, supposedly 'real' durwan. In "A Real Durwan", it is explicitly expressed that maintaining a vigil, "under normal circumstances ... was no job for a woman" (Lahiri, 1999, p. 81), and what the residents of the building eventually decide to do is to hire a 'real' durwan that would 'not lie', that would 'not betray'. The story is one of many diaspora writings by Lahiri in which the female protagonist - in this case, the uprooted Boori $\mathrm{Ba}$ - is not only a naïve victim of a social conspiracy, but she is also parodied, criticized, and eventually punished for her role in taking up a vigilant gaze.

Boori Ma watches on behalf of both male and female residents of the building and as long as she succeeds in remaining outside the circuit of her own desire, she is an effective observing agent for the residents who employ her. The gaze here therefore seems to be inverted, and through permitting a female character to take a controlling gaze, the story seems to destroy the "hierarchical positioning of male and female that the gendered gaze entails" (Newman, 1990, p. 1037). But what Lahiri suggests in the story is ultimately anti-feminist and gynophobic, since the power of the gaze that enables Boori Ma is being parodied. Things escape Boori Ma's vigilant observations, disabling her ability to explain- 
in particular, the final crucial moment when she meets the overarching gaze of Mr. Chaterjee and fails to justify her leave.

"A Real Durwan" offers an example of the formative split between the eye and its gaze. The narrative is about the period of time in Boori Ma's life following her separation "from a husband, four daughters, a two-story brick house, a rosewood almari", and how the several "losses" and a near-death "plight" that have finally led to her "deportation to Calcutta after Partition" cause her to see the world anew. The reader, however, is not given access to the inner process of this transformation, so that what predominates is a subjective but detached narration which casts doubt on the reliability of Boori Ma's own words: "Whether there was any truth to Boori Ma's litanies no one could be sure. For one thing ... she garbled facts. She contradicted herself. She embellished almost everything. But her rants were so persuasive, her fretting so vivid, that it was not so easy to dismiss her" (Lahiri, 1999, p. 79). The narrative is hence woven around what Boori Ma sees or fails to see and her repeated expression "Believe me, don't believe me". Whereas she is expected to act as a guard between the residents "and the outside world", Boori Ma is depicted as trapped in her own visual trauma, split from the symbolic and imaginary reality of the rational world around her. As most of the wives in the neighborhood collectively surmise, "she probably constructs tales as a way of mourning the loss of her family" (Lahiri, 1999, p. 80). Her trauma makes her aware of the real in the realm of the visible, "as an object a, an object most other subjects would view as ordinary" (Manlove, 2007, p. 91). For instance, her shaking "the mites out of her bedding", and her hoping "to identify the culprit of her sleepless nights" reveals the extent she is terrified and paralyzed; while, a fellow resident, Mrs. Dalal, confesses she does not see anything.

In assuming the role of a "guard', who "patrolled", "screened" and "maintained a vigil", Borri Ma is thus granted a "masculine" position, which, because she is a woman and "this was no job for a woman", redefines her as "monster" or "witch". In addition, although Boori Ma possesses an active male gaze that provides her with the pleasure of looking, and to a large extent defers her confrontation with the fact of castration-for such "undisturbed looking returns the subject to the sense of completeness associated with the scopophilic pleasures of the Lacanian mirror stage" - she is also a passive victim of another, more powerful gaze. This is the gaze of the "highly esteemed" Mr. Chatterjee, who has not "strayed from his balcony" since independence, but whose final assertion exiles Boori Ma out of the building, thus making the story end with a capitulation to the ideology of the patriarchal judge. Thus, the argument of the present essay is reinforced, that almost all Lahiri's works share a fundamental, unavoidable characteristic, of being directly concerned with American culture's carceral machinery at work. Nearly every story reiterates Bentham's Panopticon idea: the model prison that signals the metamorphosis of liberalism into total scrutability.

The Panopticon we encounter at the end of "A Real Durwan" departs from the Benthamite ideal in a significant way. Mr. Chaterjee, who has appeared to be the all-knowing person of the apartment, is figuratively, not literally, at the center of the story's Panopticon, as he observes his neighbors from the balcony, a peripheral position in the apartment building rather than from its hub. His peripheral position, however, does not necessarily imply that the efficacy of panoptic power has been diminished: rather, such a dislocation of the gaze from a central stand to a marginal one is a visual literalization of Foucault's proposition of the Panopticon's "capillary" dissemination of power relations. According to Foucault (1995), "The efficiency of power, its constraining force have, in a sense, passed over to the other side - to the side of its surface of application. He who is subjected to a field of visibility, and who knows it, assumes responsibility for the constraints of power" (p. 202). The absence of such a central visual standpoint in the Panopticon of Lahiri's "A Real Durwan" reveals the degree to which "its deployment of disciplinary control mechanisms has been successful-panoptic surveillance is now so pervasive that these mechanisms have been effectively internalized, thus obviating the need for the constant visual reminder of the guard tower at the heart of the panoptic machine" (Hurley, 1997, p. 35). Zizek regards this power operations of the gaze as an ongoing insecurity in those who are being looked at: the Panopticon is horrifyingly efficient due to the fact that the subjects "can never know for sure if they are actually observed from the all-seeing control tower-this very uncertainty intensifies the feeling of menace, of the impossibility of escape from the gaze of the Other" (Hurley, 1997, p. 92).

\section{Self as a being for another}

“Only Goodness" is another of Lahiri's stories in which a female figure, named Sudha, takes the role of spectator and "tragically fails in her responsibility" to both her first family and "her own second or "fledgling family", , or husband and child (Hai, 2012, p. 184). The story is about an Indian family that move to London then move to America. Sudha, the female protagonist, is Rahul's older sister, and ever since Rahul was born, she has a pivotal, controlling role in his upbringing. Sudha introduces alcohol to Rahul when he is still a high school student. Drinking gradually turns him into a misfit, an alcoholic Cornell-dropout. Rahul's dismissal from college devastates their parents and puts the family reputation in serious danger. The narrative continues by unpacking Rahul's other disappointments in life, for every one of which Sudha blames herself, admitting her failure in rearing him properly. Sudha marries a British man and moves to London to start a new life. There she gives birth to a boy named Neel. Sudha, still unable to resist the claims of alcoholic Rahul, on his visit to London, leaves him to babysit Neel. Rahul gets drunk again and leaves the baby Neel in the bathtub. Once again, Sudha, through her trust in Rahul, endangers the life of her child and the stability of her marriage, in the loss of her husband's trust. Rahul's alcoholism continues to worsen to the point that one day, when he is driving, he is arrested by the police.

Following Rahul's arrest by the police and his court session, the narrator turns its attention to a scene where Sudha wanders through the National Gallery, and stops to admire a Dutch oil painting, The Arnolfini Marriage, by Jan van Eyck: 
It was an oil painting of a couple in a bedroom holding hands, with a small dog standing at their feet. The man wore a fur-trimmed purple cape and an overly large black straw hat. The woman wore an emerald-green gown that trailed like a heavy curtain onto the floor, some of the material gathered up in her left hand. She had a white veil on her head and looked possibly pregnant, Sudha wasn't sure. There was a window behind the man, with a piece of fruit, an apricot or a tangerine, on the sill. On the wall hung a convex mirror that reflected everything in the painting. (Lahiri, 2008, p. 145)

What follows reinforces the fact that Sudha's assuming the role of spectator, as her supervision of Rahul has already proved, is ineffective. In order to see, her female gaze has to be cast through masculine lenses, "Otherwise you [Sudha] can't really see" (Lahiri, 2008, p. 145). The remark recalls E. Ann Kaplan's statement that "The gaze is not necessarily male (literally) but to own and activate the gaze given our language and the structure of the unconscious is to be in the 'masculine' position" (as cited in Newman, 1990, p. 1029). "Ushering her a few steps forward", the man next to her, named Roger, starts "talking about the mirror, how it was the focal point of the painting, capturing the floor and the ceiling, the room and the world outside", and it is only after he instructs her how to read the painting, that "she saw that it [the mirror] reflected not only the couple but also a pair of men standing in the doorway, peering into the room just as she was" (Lahiri, 2008, p. 145). Lahiri's choice of this famous painting, itself a portrait of a couple being seen by two men and the two observers being seen watching is no accident. The scene is noteworthy in several seemingly distinctive yet interrelated ways: First, it suggests that a female's subjectivity is formed only when she puts on masculine spectacles. Here it is ' $\mathrm{I}$ ', the female subject that ultimately takes shape, as if to underline the fact that the female subjectivity comprises the whole point of Lahiri's fiction. In Television, Lacan says about the relation between the I and the gaze: "The gaze is that which 'determines' the I in the visible; it is 'the instrument through which ... [the] I [is] photo-graphed" (Copjec, 1989, p. 298). In this case, the gaze operates to determine the complete visibility of Sudha, the I, producing a centered and transcendent female subject. Lacan's 'misrecognition', "implies that there is another actual, nonpunctiform position" (Copjec, 1989, p. 298). He explicates this with a humorously recondite story about his looking at a sardine can, which, floating on the sea, "was looking at me at the level of the point of light, the point at which everything that looks at me is situated - and I am not speaking metaphorically" (as cited in Storr, 1994, p. 255). Here, Lacan's "point of light" operates as "the point of the look", determining the subject in the visible world by means of "photo-graph[ing]" it. As he explains,

This is the function that is found at the heart of the institution of the subject in the visible. What determines me, at the most profound level, is the gaze that is outside. It is through the gaze that I enter light and it is from the gaze that I receive its effects. Hence it comes about that the gaze is the instrument through which light is embodied and through which -if you will allow me to use a word, as I often do, in a fragmented form - I am photo-graphed. (1998, p. 106)

The significance of the sardine can, and its relevance to our reading of Lahiri's story lies in the fact that, here, the conventional Cartesian proposition of the subject as a point of perspective is conceived no longer as a visual concept of the subject, rather, as one with an internal dialect: perspective is thus a matter of geometry: not that of a "single triangle that geometrical perspective draws as an accurate description of its own operation", but rather, as an operation that engages "two interpenetrating triangles" (Copjec, 1989, p. 298). The place of the Lacanian subject in this scopic realm, "is therefore not as a point of perspective, but as an 'object' caught in the play of light. As Lacan (1998) explains it:

I am not simply that punctiform object located at the geometral point from which the perspective is grasped ... That which is light looks at me, and by means of that light, in the depths of my eye, something is painted ... something that is not simply a constructed relation, the object on which the philosopher lingers - but something that is an impression, the shimmering of a surface that is not, in advance, situated for me in its distance. This is something that introduces what was elided in the geometral relation - the depth of field, with all its ambiguity and variability, which is in no way mastered by me. It is rather it that grasps me, solicits me at every moment, and makes of the landscape something other than a landscape, something other than what I have called the picture. (p. 96)

In this regard, "vision by its very nature as play of light maps the subject as looked-at ... as visible” (Storr, 1994, p. 256). As soon as the subject realizes that things are looking back at it, it also recognizes that its so far supposed "autonomy as seeing subject - as a point of perspective on the world - is illusory" (Storr, 1994, p. 256). It is this reemergence of visibility — of being looked-at — that is reinforced by displaying "secret presences in the painting's mirror" (Hai, 2012, 194) as the "focal point" of van Eyck's painting. Most obviously, the painting embodies Sudha and Roger's shared visual frame and their being the object of both the narrator's and the reader's gaze. Lacan's basic structure of vision, given in The Four Fundamental Concepts of Psycho-analysis as a split between the eye and the gaze, may illuminate the connections between the subject's seeing, and his seeing himself seeing: "we are beings that are looked at, in the spectacle of the world. That which makes us consciousness institutes us by the same token as speculum mundi" (1998, p. 75). In this manner, although their shared gaze situates both Sudha and Roger in the place of the subject in the dialectic between the eye and the gaze, it simultaneously reflects their being look-at-ness in the visible world, reflecting Lacan's statement that "I see only from one point, but in my existence I am looked at from all sides" (1998, p. 72). This point, at which the subject appears to be visible, at which the subject "cannot be located or locate itself at the point of the gaze, since this point marks ... its annihilation" (Copjec, 1989, p. 300), is the point where we raise the question, what is it that is at stake when the gaze is cut off from the subject? Or how is subjectivity affected 
when the subject realizes a possibility opened up by the law of the Other? Lacan neither answers these questions nor does he say that one must "think of the gaze as belonging to an Other who cares about what or where you are, who pries, keeps tabs on your whereabouts, and takes notes of all your steps and missteps, as the panoptic gaze is said to do" (Copjec, 1989, p. 301).

As a visual apparatus, the painting, appearing at the heart of the story, thus operates to instantiate in its viewers, in particular Sudha, the ideological interests of the disciplinary society by, first, conscripting her - as the painting is instructed to her by Roger-into a scopic illusion, where she is provided with a voyeuristic modality to feel the pleasures of mastery and control, and then, constituting in her a form of captivation by reinforcing a perpetual possibility of being watched. The painting, to take a Foucauldian position, thus turns into a "trap for the gaze", operating to trap the subject, Sudha, in representation, and constructing the invisible prison walls of her being.

If, however, prison might seem invisible in "Only Goodness", the people who imprison, the police, whose panoptic gaze defines the situation of Sudha under patriarchy and in a sense parodies her monitoring gaze, are not. The parody starts with Rahul's brutal questioning of Sudha's knowledge, "What the fuck do you know? .... words [that] silenced her, cut[ting] to the bone" (Lahiri, 2008, p. 141), continues with Sudha's acknowledging her failure, "I don't get it" (Lahiri, 2008, p. 141), and ends with the emergence of the police as a regulatory force to implant the law, establish orderliness, and imprison the criminal, Rahul. Prison, "modernity's most starkly visible carceral apparatus" (Hurley, 1997, p. 14), thus makes a timely appearance in "Only Goodness", making the story a register and a participant in the social, sexual, and political 'paranoia' of the American cold war and its resulting emergence of the oriental Other. When we hear Rahul's profound interest in writers like Beckett and Marx, uttered "with an aggressive authority, as if he'd been to Marx's tomb himself" (Lahiri, 2008, p. 142), the narrative focus shifts from Rahul's resistant attitude upon his "calling from the local police station ... to ask Sudha to come to the station" and release him. As we are told, "He'd been pulled over on a quiet road near Mill Pond ... to [be] arrested" (Lahiri, 2008, p. 142).

Though the scene is brief and the encounter with police is a cursory event, its significance lies in the fact that prison for both Lahiri and her Indian characters seems so terrifying as to be almost beyond imagining. For Sudha's father, "the local police station" is a place of such great horror and shame that it and the people consigned to it must be avoided, and to employ Hurley's terms: "must be exiled to the borders of the narrative" (1997, p. 14). Consequently, when Sudha and her father arrive at the police station to "post bail and release Rahul", the father remains in the car and says, "YYou go,'... 'I prefer to wait in the car.' His voice faltered as he spoke .... And so she spared her father that humiliation, that pain, entering a place where handcuffed criminals were brought" (Lahiri, 2008, p. 143). For Rahul's mother, however, it is not only the police who do not occupy a delimited social space-where it would have a clearly defined social function - but it operates as regulative apparatus of the powerful state to produce racialized and gendered identities. For the mother, the disciplinary powers of state, its normative ways, and the governmentality of freedom for the production of American nationalism "is ridiculous". The next morning, "she blamed the police for overreacting. 'It's not like he had an accident. He was only going forty miles an hour. They probably stopped him just for being Indian [my emphasis] ... That's the problem with this country"' (Lahiri, 2008, pp. 142-3).

The story's portrayal of the police is especially interesting in regard to Lahiri's allusion to Alfred Hitchcock's movie, Spellbound (1945). When Rahul calls from the police station, Sudha "was up watching Spellbound on the VCR" (Lahiri, 2008, p. 142). The allusion is significantly in keeping with the story's fundamental ideological belief in the power of the eye of authority, and the subjects' self-disciplining, in two ways. In the first place, Hitchcock's own horror of the police is well known. As Hurley observes, "[I]n what is without doubt the most famous anecdote from his personal life, Hitchcock, five or six years old, is sent by his father to the local police station with a note saying he has misbehaved and should be locked in jail. 'This is what we do to naughty boys,' scolds the obliging constable, closing a cell door on the child" (1997, p. 13).

In a similar way, Rahul is also arrested not because his blood alcohol content was extreme, but because "he was under twenty-one" (Lahiri, 2008, p. 142), or vulnerable to the same kind of authoritarian intimidation suffered by the child Hitchcock. Second, Spellbound, in contrast to Rahul's mother who criticizes the disciplinary society for "overreacting" and incarcerating and criminalizing certain kinds of bodies, advocates neoliberal rhetoric of individualism and dissociates the subject's subjectivity from the sexual and social politics of the society. In neoliberal rhetoric, as McWhorter (2013) observes, "Individuals must assume the risks and the costs of pursuing their goals. Individuals must suffer the consequences of their mistakes .... This rhetoric of individualism makes talk of privileged or oppressed groups difficult to sustain. On the prevailing neoliberal view, people always act and are acted upon as individuals" (p. 62). In like manner, Spellbound, which is an American psychological thriller, opens with the Shakespearean proverb, "The Fault... is Not in Our Stars, But in Ourselves", and thus disseminates the ideology that the individuals must turn to themselves and practice self-discipline. As a consumer of the state culture, Sudha responds in a parallel manner with the prevailing neoliberal rhetoric to her brother's social transgression, and thus "pitied her mother, pitied her refusal to accommodate such an unpleasant and alien fact, her need to blame America and its laws instead of her son" (Lahiri, 2008, p. 143). Such an understanding of the crime, on the part of Sudha, reflects, to a large extent, her internalization of a powerful form of governmentality against racial minorities in the US, that scholars like Inderpal Grewal (2003 \& 2005) identify as 'risk' and 'danger'. The rich passage in which Grewal (2003) explicates the situation is worth citing at some length

Through the twentieth century, risk emerged as a mode not only of judging actions and events but also of bodies ... the synonym for risk is ... danger and 'terror', and the means for securing the population 
from this danger is the incarceration of other populations judged by various modes of expertise as dangerous. From the 'criminal' as one level of risk for violence, to 'terrorist' as the designation of the person who is a risk to the nation, we can see the progressively higher levels of risk associated with particular bodies within specific locations. ... Such an understanding of 'risk' can enable us to see the ways in which the identifications of 'populations at risk' are allied both to the idea that racial and gendered (and often sexual) minorities are a danger to themselves and to others and thus have to be subject to forms of regulation and self-regulation. (p. 539)

\section{Conclusion}

Literature might be considered as an apparatus that establishes ideological images of power and plentitude. In order to materialize the literary gaze, this essay has focused on Lahiri's diasporic writings, "A Real Durwan" and "Only Goodness," as they offer the several advantages of showing the process of gazing, subjects looking and being looked at, the affects and effects of those gazing subjects, and the way that their literary gaze formulates and structures the literary discourse in which they are located. Lahiri's postcolonial narratives provide the further advantage of locating their looking subjects-Boori Ma in the former story and Sudha in the latter one-in various positions of seeing surrogacy, making them objects for some of the instances of the gaze that take place through the literary apparatus: the gaze of the character, the gaze of the narrator, the gaze of the reader, and the gaze of the author herself. In her narratives, to employ Foucault's words, "the gaze is alert everywhere" (1995, p. 214), it is obsessive and transgressive, "it refuses to cease, even when it is in its own interests to do so; refuses to respect intimate spaces, even when such violation brings about for the gazer...shame, shock, or pain" (Hurley, 1997, p. 6). In this, the narratives practice the preoccupation of Lahiri's fiction, its fascination with the gaze and objectifying of the subject, while commanding attention from the reader even when narrating scenes that seem intrusive.

In situating her stories within the structure of the biased American literature-as an ideologically-informed and politically expedient institution - this essay concludes that Lahiri's fiction is paradigmatic of this phenomenon, i.e. the ideological institution. The law and order apparatus of policing, surveillance and incarceration hence forms the backbone of her stories. The failure of both Boori Ma and Sudha in the practice of watching - the former as the guard of an apartment building, and the latter in monitoring her little brother Rahul-the subsequent intervention of the regulatory regime, the self-disciplinary ideologies disseminated by social technologies, and the dissociation of the seeing/being seen dyad, which is reinforced through Mr. Chaterjee in "A Real Durwan" and the mirror as the focal point of the painting in "Only Goodness", generates a sense of the permanent visibility of these female protagonists whose self-image is thus described as a function of their being-for-another which entails monitoring their selves with a patriarchal eye.

Through such a process of privileging masculinity, Lahiri's fiction thus implicitly relegates the female to the status of spectacle, so that rather than being the subject doing the looking, the woman functions as a passive object to be looked at. Besides, when the woman does assume the role of spectator, there is a strong element of parody involved. In this regard, the essay concludes that Lahiri's stories comply with the ideological belief lying at the heart of Western culture that the gaze is the privilege of a male subject. This fascination with the idea that the woman must not watch is most clearly reflected in "A Real Durwan" and later picked up with more subtle twists in "Only Goodness". In each case, the woman looks only on behalf of patriarchy, her main task being, quite literally, to monitor: In the former, the woman's look is supposed to operate as an effective policing agent, and in the latter, it is in the service of regulating the family.

\section{Acknowledgments}

The research is done at the expense of the prestigious USM Global Fellowship granted in 2015 to Mr. Moussa Pourya Asl to pursue his Doctoral studies in English Literature at Universiti Sains Malaysia.

\section{References}

Asl, M. P., Hull, S. P., \& Abdullah, N. F. L. (2016). Nihilation of femininity in the battle of looks: A Sartrean reading of Jhumpa Lahiri's "A Temporary Matter". GEMA Online Journal of Language Studies, 16(2).

Asl, M. P., Abdullah, N. F. L. \& Yaapar MD. S. (2016). Mechanisms of mobility in a capitalist culture: The localization of the eye of (global) authority in the novel and the film of Jhumpa Lahiri's The Namesake. KEMANUSIAAN: The Asian Journal of Humanities, 23(Supp.2):137-159

Copjec, J. (1989). The orthopsychic subject: Film theory and the reception of Lacan. In E. A. Kaplan (Ed.), Feminism and film (287-306). Oxford University Press.

Cussen, J. (2012). The William Morris in Jhumpa Lahiri's wallpaper/and other of the writer's reproofs to literary scholarship. Journal of Ethnic American Literature, 2, 5-72.

Dhingra, L., \& Cheung, F. (Eds.). (2012). Naming Jhumpa Lahiri: Canons and controversies. Lexington Books.

Dhingra, L. (2012). Feminizing men?: Moving beyond Asian American literary gender wars in Jhumpa Lahiri’s fiction. In L. Dhingra \& F. Cheung (Eds.), Naming Jhumpa Lahiri: Canons and controversies (135-155). Plymouth, UK: Lexington Books. 
Fetterley, J. (1997). Introduction: On the politics of literature. In R. Warhol-Down \& D. P. Herndl (Eds.), Feminisms: An anthology of literary theory and criticism. Rutgers University Press.

Foucault, M. (1995). Discipline and punish. (A. Sheridan, Trans.). New York: Vintage. (Original work published 1977) Ganguly, K. (2001). States of exception: Everyday life and postcolonial identity. University of Minnesota Press.

Grewal, I. (2003). Transnational America: Race, gender and citizenship after 9/11. Social Identities, 9(4), 535-561.

Grewal, I. (2005). Transnational America: Feminisms, diasporas, neoliberalisms. Duke University Press.

Hai, A. (2012). Re-Rooting families: The alter/natal as the central dynamic of Jhumpa Lahiri's Unaccustomed Earth. In L. Dhingra \& F. Cheung (Eds.), Naming Jhumpa Lahiri: Canons and controversies (181-210). Plymouth, UK: Lexington Books.

Hurley, J. S. (1997). After the panopticon: Surveillance, scopophilia, and the subject of the gaze (Unpublished doctoral dissertation). University of Virginia, Virginia, The United States.

Koshy, S. (2013). Neoliberal family matters. American Literary History, 25 (2), 344-80.

Lacan, J., \& Miller, J. A. (1998). The four fundamental concepts of psycho-analysis (Vol. 11). WW Norton \& Company.

Lahiri, J. (1999). Interpreter of maladies. New York, Houghton Mifflin Harcourt.

Lahiri, J. (2008). Unaccustomed earth: stories. New York \& Toronto, Alfred A. Knopf.

Lynn, D. H. (2004). Virtues of ambition. The Kenyon Review: New series, 26 (3), 160-166.

Mani, B. (2012). Cinema/Photo/Novel: Intertextual readings of "The Namesake". In L. Dhingra \& F. Cheung (Eds.), Naming Jhumpa Lahiri: Canons and controversies (75-96). Plymouth, UK: Lexington Books.

Manlove, C. T. (2007). Visual drive and cinematic narrative: Reading gaze theory in Lacan, Hitchcock, and Mulvey. Cinema Journal, 46(3), 83-108.

McWhorter, L. (2013). Post-liberation feminism and practices of freedom. Foucault Studies, (16), 54-73.

Metz, C. (1997). The Imaginary signifier: Psychoanalysis and the cinema. Indiana University Press.

Mohanty, C. T. (2014). "Under western eyes" revisited: Feminist solidarity through anticapitalist struggles. Signs, $40(1), 499-535$.

Mulvey, L. (1975). Visual pleasure and narrative cinema. Media and Cultural Studies: Keyworks, 393-404.

Newman, B. (1990). "The situation of the looker-on": Gender, narration, and gaze in Wuthering Heights. Publications of the Modern Language Association of America, 1029-1041.

Obama, B. (2015). "Remarks by the President at the National Medals of the Arts and Humanities Awards Ceremony". Retrieved 16 November 2015. https:/www.whitehouse.gov/the-press-office/2015/09/11/remarks-president-nationalmedals-arts-and-humanities-awards-ceremony.

Reddy, V. (2013). Jhumpa Lahiri's feminist cosmopolitics and the transnational beauty assemblage. Meridians: Feminism, Race, Transnationalism, 11(2), 29-59.

Spivak, G. C. (1988). Can the subaltern speak?. In C. Nelson, \& L. Grossberg (Eds.), Marxism and the interpretation of culture (271-313). University of Illinois Press.

Spivak, G. C. (1997). Three women's texts and a critique of imperialism. In R. Warhol-Down \& D. P. Herndl (Eds.), Feminisms: An anthology of literary theory and criticism. Rutgers University Press.

Spivak, G. C. (1999). A critique of postcolonial reason. Harvard University Press.

Srikanth, R. (2012). What lies beneath: Lahiri's brand of desirable difference in Unaccustomed Earth. In L. Dhingra \& F. Cheung (Eds.), Naming Jhumpa Lahiri: Canons and Controversies (51-74). Plymouth, UK: Lexington Books.

Storr, M. J. (1994). The gaze in theory: The cases of Lacan and Sartre (Unpublished doctoral dissertation). University of York.

\section{Notes}

${ }^{\mathrm{i}}$ When we see how female characters must emigrate due to an arranged marriage imposed on them by the patriarchal culture.

ii Dhingra explains that the Asian American women writers align themselves with feminist critics because, like them, they attempt to examine the female self and subjectivity. In their literature, it is the male characters who are usually marginalized and as Elaine Kim points out, "it is women characters who strive, and sometimes they win. Their heroic reconstruction is accomplished without or despite the men" (as cited in Dhingra, 2012, p. 136). Dhingra argues that empowering of female characters necessarily involved an emasculation of Asian males in American society, but she excludes Lahiri from this circle of Asian American women writers. She points to Lahiri's timely renegotiation of Asian American sexual politics at the start of twenty-first century and affirms that unlike her predecessors, she depicts Bengali 
American male characters as "amiable, intellectual, caring, sensitive, thoughtful, often nurturing, and certainly not villainous" (2012, p. 141).

iii Dhingra believes this privileging of masculinity is itself part of Lahiri's revolt against the constructed colonial representations of Bengali males as effete. During the British nineteenth-century rule of India, Dhingra tells us, the Bengali gentleman "was considered effeminate in contrast to the "manly' Englishman" (2012, p. 143). Osella and Chopra describe the binary constructions of British and Indian masculinity thus: "The British were hyper-masculinized, scientific and progressive, a high step on the evolutionary ladder; the Indians were effeminate, childlike, primitive, and superstitious" (as cited in Dhingra, 2012, pp. 143-4). Dhingra states that, traditionally, Asian American men were similarly feminized, and what Lahiri does is challenge this particular mode of oppression and marginalization.

iv Durwan literally means a porter or doorkeeper whose major responsibility is to oversee order in the building and clean all the public areas.

${ }^{v}$ It refers to the partition of India in 1947 which led to the creation of two independent countries: Hindu-majority India and Muslim-majority Pakistan. 